\title{
Does Money Matter? Childbearing Behaviour of Swedish Students in the 1980's and 1990's
}

\author{
SARA THALBERG, Ph.D. student \\ Department of Sociology, Demography unit, Stockholm University, Sweden
}

\begin{abstract}
Education is considered to be one of the primary factors behind postponement of childbearing, as students have significantly lower fertility than non-students of the same age. The low fertility of students may have many different explanations. This study focus on the impact of economic and policy factors on the relationship between study enrolment and childbearing in Sweden. Using longitudinal data it is examined whether the student financial aid reform of 1989 had any effect on female students' child $\neg$ bearing behaviour and whether female students' relative child $\neg$ bearing propen $\neg$ si-ties change when controlling for their earned income. The results show that the reform had no noticeable impact on students' childbearing behaviour. However, first birth risks for female students in all age groups are clearly related to earnings, indicating that the postponement of childbearing until completion of education is, to some degree, a matter of economic constraints.
\end{abstract}

Key words: Sweden, students, childbearing, fertility, education

\section{Introduction}

The massive educational expansion was one of the most fundamental social changes in Europe at the end of the $20^{\text {th }}$ century. Both the number of students and years spent in higher education increased substantially. Compared to other European countries Sweden has one of the highest percentages of tertiary educational attainment in Europe. In 2004, 42 percent of 25 to 34-year-olds in Sweden had attained tertiary education (OECD 2006). International comparisons also show that Swedish students are relatively old. Swedes have one of the highest average ages of entry into university and leave university at a high age. The median age for completion of a first degree is 28 years, and one in three students is above age 30 (Statistics Sweden 2009a; SOU 2003:130). Despite being in prime childbearing ages, few students have children while still being enrolled.

Low fertility among students may have many explanations. The most obvious explanation perhaps is that students' low or non-existent earnings are generally not perceived to be compatible with the establishment of a family with children. Another explanation may be that the student life style is not seen as being compatible with having children. Other explanations may involve social norms about the necessity of getting established 
in adulthood in other ways before having children, which by many is considered the last and major transition into adulthood. In Sweden, the design of the parental leave system may be an additional cause related to the "low earnings factor". As the parental leave benefit is based on an individual's prior earnings, low earnings also entail a low parental leave benefit. Students who did not work before enrolment are not eligible for earnings-related parental leave benefit and instead receive a benefit at a low, flat rate. ${ }^{1}$ Since parental leave is rather long in Sweden - most mothers stay at home for at least a year - the benefit level is quite essential. In 1999, only 3.6 percent of all mothers on parental leave, and 0.7 percent of the fathers, received parental leave benefits at the low flat rate, indicating a pervasive "first-job-then-children" mentality (Ds 2001:57). ${ }^{2}$

The emergence of the welfare state has been said to be a key factor behind the "institutionalisation" of the life course, particularly with regards to educational trajectories and the transition to parenthood (Mayer and Müller 1986). The different factors related to the low fertility of students are naturally intertwined. For example, the Swedish parental leave system strongly reinforce the social norm that one should complete education and enter the labour market prior to having children, at the same time as parental leave legislation is influenced by societal norms. The parental leave system is part of a larger social policy package which includes welfare components such as access to subsidized childcare, housing allowances, student financial aid and free education - all which influence young adults' behaviour in the transition to adulthood, and their sequencing of life events.

The focus of this study is the impact of economic and policy factors on the relationship between study enrolment and childbearing in Sweden. Using longitudinal data on individual childbearing and study activity between 1984 and 1999 various aspects of this relationship is studied. To begin, it is explored whether the relative propensity of female students to have a first-, or subsequent child has been affected by changes in the student financial aid system. Then the importance of earned income is investigated by controlling for whether income alters female students' relative propensity to have a child. Given that childbearing risks strongly differ by age, it is examined whether the impact of student financial aid and income differs by age group.

As the Nordic countries in general, and Sweden in particular, are often used as a reference when discussing the possible impact of various family policies on fertility behaviour, it is valuable to complement previous demographic research with a study that specifically addresses the circumstances for students. The findings will give some indication of the importance of economic factors and whether moderate changes in student financial aid may matter for childbearing decisions. The study will also contrib-

1 At the time period studied in this paper the flat rate was $60 \mathrm{SEK} /$ day (about $6 €$ ). Since then the amount has been raised to $180 \mathrm{SEK} /$ day.

2 This percentage refers to Swedish-born parents. Among foreign-born parents the share receiving parental insurance at the low flat level is much higher. 
ute to a more nuanced understanding of the potential effects of social policy reforms on family formation. Given that students all over Europe have low levels of fertility, and that the possibility of stimulating an earlier onset of childbearing sometimes is suggested as a remedy for falling fertility in Europe (see for example Skirbekk et al. 2004; Lindh 2008), exploring childbearing behaviour among students is highly relevant from a European demographic perspective. As longevity is expected to continue to rise, it is hypothesized that the period of time spent in educational pursuits will also continue to rise (Lee and Goldstein 2003). Thus, facilitating having children while still in education may be one way to impede further postponement of childbearing.

In the following section, a contextual background of childbearing trends and the Swedish student financial aid system is given. Thereafter follows a theoretical discussion on the link between enrolment and childbearing, and the various factors influencing this relationship. Section four discusses data and methods followed by empirical results in section five. Finally, the main findings are summarized and discussed in section six along with suggestions for future research.

\section{Fertility and student aid in Sweden}

Like most European countries, Sweden has experienced a postponement of parenthood in recent decades. Yet, despite the higher age at first birth, the Total Fertility Rate (TFR) in Sweden is currently one of the highest in Europe. Conversely, Sweden has experienced strong pro-cyclical fluctuations in its fertility levels in recent decades, where levels of female earnings and labour force participation are positively related to levels of childbearing (Andersson 2000). During the economic upturn in the late 1980s fertility increased considerably and in 1990 and 1991 TFR even exceeded replacement at 2.10 births per woman. Thereafter followed an economic crisis and a subsequent dramatic drop in TFR. One of the most important factors contributing to the decline in fertility during the 1990s was young people's weak labour market attachment. When the market went into crisis, this weak attachment to the labour market lead to a dramatic rise in student enrolment which, given the low fertility of students, had quite a substantial impact on aggregate fertility levels (Hoem 2000). When the economy recovered, fertility levels began to rise as well and in 2008 the TFR reached 1.91 (Statistics Sweden 2009b).

Comparative research shows that entering parenthood while still in education is more common in Sweden and the other Nordic countries, than it is elsewhere in Europe (Billari and Philipov 2004). The higher rate of parenthood is most likely related to higher ages of students and the relatively generous family policy. Although students without previous work experience are excluded from the income-based parental leave insurance, students have access to subsidized public childcare, child benefits and parental leave benefit at a low flat rate. ${ }^{3}$

3 To be entitled to the earnings-related parental insurance one has to work for a minimum of 240 days before the birth of the child. 
Students cannot receive full-time student financial aid and full-time parental leave benefit at the same time, but students may obtain financial aid for parttime studies along with a reduced amount of parental leave benefit. University studies are free of charge and the state offers fairly generous financial assistance consisting of grants and low-interest loans. All students below age 54 who are enrolled in higher education are entitled to student financial assistance for a maximum of 12 semesters. ${ }^{4}$ This aid consists of a non-repayable grant plus a loan to be repaid with low interest. One of the aims of this financial aid package is to increase social mobility and ensure that young people are financially independent of their parents. More than 80 percent of all students in Sweden receive some kind of student financial aid.

Even though the student financial aid is quite generous compared to many other countries, it is considerably lower than an average worker's wage (for a detailed comparative overview of financial support for students in higher education in Europe, see Eurydice 1999). Since the early 1990s, the gap between an average worker's wage and the student financial aid has increased. While workers' wages have increased rapidly, student financial aid has remained at the same level. According to calculations by Swedbank (a major Swedish bank), a single student who receives both the non-repayable grant and loan has, net all "necessary" expenses, about 200 SEK ( $€ 20)$ remaining each month. ${ }^{5}$ To support a child on this income is difficult unless the student has a partner with a high income. In 2007, 25 percent of all students also received financial support from their parents or other relatives, and 60 percent worked part-time to make ends meet (Statistics Sweden 2007). However, there is a limit to how much students are allowed to earn before their student financial aid will be reduced. For those who obtain full student financial aid, the limit is set to 53.000 SEK ( $€ 530)$ per semester. $^{6}$

In 1989, a student financial aid reform took place in which regulations for loan repayment were changed, and the non-repayable grant was raised along with financial assistance for studies abroad. However, the possibility of obtaining additional loans for children, the so-called child supplement, was also eliminated. The child supplement had been calculated on the number of children - the more children the higher the additional loan that student parents were entitled to (CSN 2008a). The reform hereby had the consequence that for students with more than one child total financial aid was reduced. Due to the raise in the non-repayable grant, however, the economic situation for students with $0-1$ child was improved by the reform (see figure 1).

4 One semester equals to about 20 weeks.

5 This calculation is for 2007 and assumes that the student receives housing allowance, which only about 14 percent of all students do. If the student does not receive housing allowance he or she is likely to run at a loss.

6 In 1990 this limit was 34.100 SEK (in 2007 prices). 


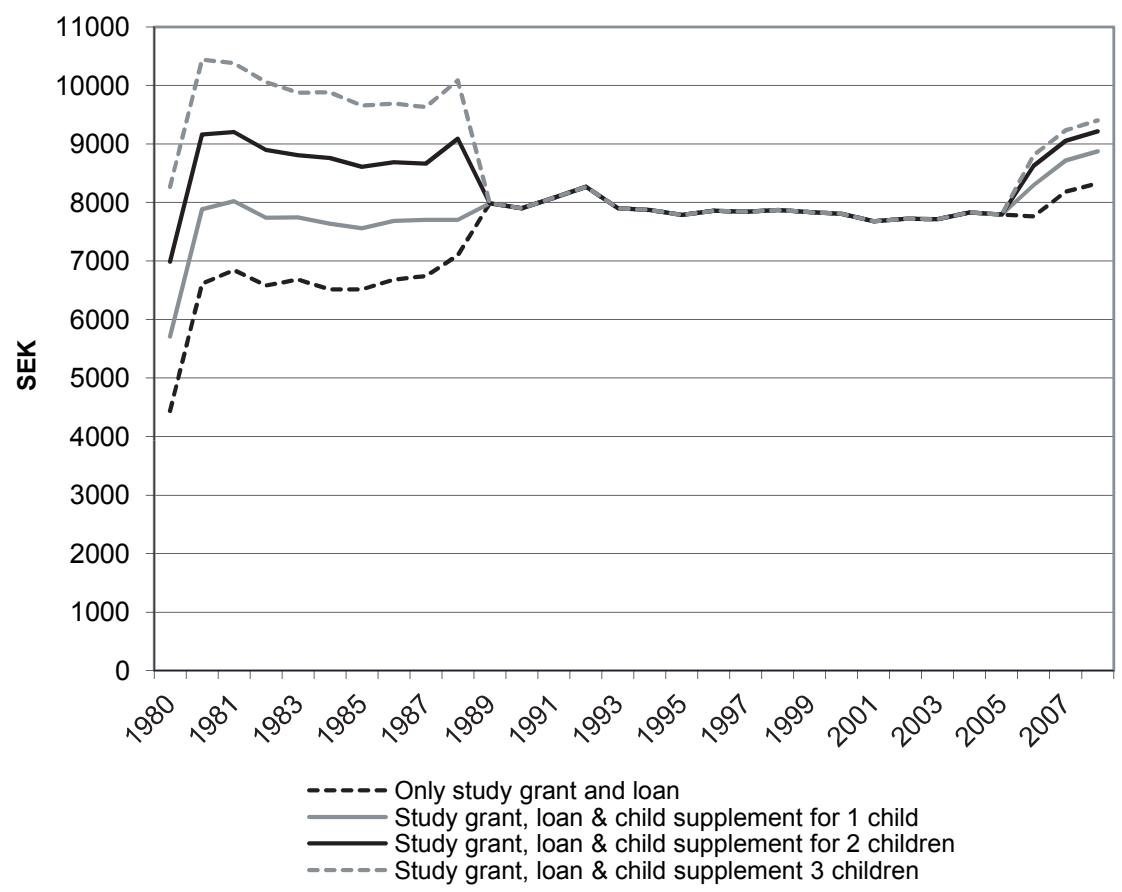

Figure 1. Student grants, loans and child supplements for parents with one, two and three children, per month, adjusted for inflation. Source: CSN (2008b).

After the reform in 1989, there were concerns among policy-makers that the removal of the child supplement would have negative consequences for students with children. As a result, an extra child supplement for students was reintroduced in 2006 in order to support children in economically disadvantaged families, and to make it easier for parents to enrol in education (Ds 2004:33). Like the previous child supplement, the supplement reintroduced in 2006 is based on the number of children. However, unlike the previous supplement, the new supplement is a grant rather than a loan. During the first semester after the reintroduction of the child supplement as many as 21 percent of female university students and 6 percent of male students received the supplement (CSN 2008b). Thus, even though few students become parents while being enrolled, a rather large share already had children when (re)entering university, which raises questions as to forthcoming changes to the traditional sequencing of life events.

\section{Education and childbearing}

Education and childbearing are dynamically interactive processes that mutually influence one other. A number of features of the educational system, such as its structure and flexibility, may have an impact on this relationship (Hoem et al. 2006). The interplay between education and childbearing is also shaped by other institutional factors, such 
as social policy, as well as by cultural and ideational factors. Finally, at the individual level, individual abilities, preferences, values and attitudes, social class, and parental resources may simultaneously influence decisions about both education and family formation (Billari and Philipov 2004).

Social policies indicate which behaviours are expected or at least supported by the state. As such family policies both reflect, as well as create or maintain, societal norms (Neyer and Andersson 2008; McDonald 2000). There is an ongoing interplay between social development, normative development, and policy responses. If policies do not correspond to existing norms and the way that people want to live their lives, those policies could have an inhibiting effect on fertility. In Sweden, family policy is mainly directed towards the compatibility of family life and labour force participation. Therefore, the fact that parental leave benefit is based on an individual's prior earnings creates a strong incentive to get established in the labour market prior to having a child. Norms of life event sequencing, where finishing education precedes family formation could therefore be said to be built into the Swedish social security system. Given the social development where young adults complete their education and get established on the labour market increasingly later in life, this is one of the main explanations behind the postponement of childbearing. A postponement that in some cases conflicts with people's desire to have children before getting too old, and, considering that fecundity declines with age, may also have an inhibiting effect on fertility.

A number of studies have shown that educational attainment and enrolment play a central role in determining the timing of transition to motherhood. For example, women with higher education have their first child at higher ages than other women. However, it is important to distinguish between achieved educational level and enrolment. Previous research indicates that it is educational enrolment, and time spent in education, rather than educational achievement, that is significant for the timing of the transition to motherhood (Billari and Philipov 2004; Kravdal 1994; Blossfeld and Huinink 1991). After completing education, having started work speeds up the transition to first birth for women in Sweden and the other Nordic countries. In contrast, entering the labour market postpones first motherhood in Southern Europe (Billari and Philipov 2004).

The importance of economic factors and family policy in students' childbearing decisions is further highlighted in a survey carried out by Statistics Sweden in 2002. According to this survey, the share of students who responded that their economic situation to a high or a very high extent affected their attitude towards having children (while in education) was as high as 92 percent, and 64 percent responded that the social insurance system affected their attitudes toward having children to a high or very high extent (SOU 2003:130). Another survey carried out by Löfström (2003), shows that the share of young adults who consider the completion of education prior to childbearing to be important was noticeably higher in the 1990s than in the 1980s - a trend that could be related to the economic crises of the 1990s in Sweden. 
Evidently, attitudinal surveys as well as actual behaviour indicate that the norm that one should complete education and establish oneself on the labour market before having children still seems to be strong in Sweden. However, it is not clear to what extent this norm is upheld by economic factors and the aspiration for economic security and to what extent it is related to non-economic factors such as external normative pressures regarding the sequencing of life events. Neither do we know how easily the relationship between education and childbearing is changed by social policy reforms or how people respond to changes in the educational system. Previous research shows that the impact of social policy reforms varies. The introduction of the "speed premium" of the Swedish parental leave system, for example, had a clear impact on birth spacing (Andersson, Duvander and Hoem 2005; Hoem 1993), while other reforms, such as the increase to the upper limit of the temporary parental leave insurance (Eriksson 2009), had no noticeable effect on behaviour. ${ }^{7}$

In this study, it is examined whether the student financial aid reform in 1989, where the possibility to obtain additional loans for children was removed, had an impact on female students' childbearing propensities. The interrelationship between enrolment and childbearing is further explored by looking at the significance of earned income, to find out whether the observed low fertility among students comes about due uniquely to their student status or if it is compounded by the low earnings often associated therewith.

\section{Data and method}

Given the complexity of family policies and the quantity of political and socio-economic factors that may have impact on various areas of an individual's life, it is of course difficult to measure the true effect of a particular policy or event on individual behaviour. To reduce the complexity, without eliminating the dynamics and interaction with other factors, it may be useful to focus on "critical junctures" (Neyer and Andersson 2008). A critical juncture is a point in time when a significant change occurs that is likely to have an effect on, in this case, childbearing behaviour. It could be the introduction or elimination of a policy, or a major raise or drop in benefit levels. These changes occur rather rapidly and can be relatively clearly marked in time. However, consideration still has to be made to the time period prior to the critical juncture, given that the development in childbearing behaviour after the change has to be assessed in relation to the situation before the change. Moreover, people may anticipate the change and adapt their behaviour accordingly or the change may be gradual, which of course makes it more difficult to detect a possible effect. In our example, 1989 can be considered a critical juncture in terms of policy development, and we note that this juncture only applies to those enrolled as students. In order to explore whether this juncture had an effect on childbearing behaviour, we need longitudinal data that contain individual life-course behaviour and in turn link this data to the relevant juncture (Neyer and Andersson 2008).

7 The "speed premium" entitles parents to the right to keep an earlier level of income replacement for subsequent births if the child is born within a period of 30 months after the previous child. 
The data used in this study are taken from the Swedish population registry system. Data on childbearing histories of all women born in Sweden in 1945 or later are analysed and linked to information on annual income, study activity and age. The income variable is based on earned taxable income the preceding year of being considered at risk of childbirth, and is given in earning deciles of women. Income replacements during sickness or parental leave are also included in the income variable. The study variable indicates whether or not an individual has received student financial aid (study grant and/or study loan) during the year. This variable includes students enrolled in traditional accredited universities, as well as in adult education programs. ${ }^{8}$ Calendar year is included as another variable with single-year periods from 1984 to 1999.

For first births, age is a single-year variable. Since first birth patterns are known to differ considerably for younger and older women, models for women at ages 20-29 and 30-44 are estimated separately. Given that the focus here is on the interplay between university enrolment and childbearing, and not teenage pregnancies among high school students, women under age 20 are not included in the sample. Moreover, very few births occur among women under age 20. In 1990, births to women under 20 accounted for only 2 percent of all children born. ${ }^{9}$ For second and third births, as to make the data more manageable, age is given in intervals, from 20-24 years to that of 36-44. In addition, we also control for the effect of time since previous birth. Lastly since Swedish registry data do not contain information on non-marital cohabitation, information on partner earnings is not available unless the couple is married or already has a child together. This means that for first births we can only get a picture of a woman's own earnings and study activity and how these affect her childbearing. For consistency, data on second and third births are also based on characteristics of women only. Consequently, the true effect of study activity on childbearing may be partially masked by unobserved household characteristics, such as partner's income.

In sum, the study at hand analyses the effect of a number of variables on birth propensities among students and non-students. This is done by estimating intensity-regression (or proportional-hazards) models. The observation window opens at the beginning of the observation period (1984) or when the woman turns 20, and closes either at the time of birth of a child, at age 44, in case of emigration or death, or at the end of the observation period (1999). The estimates are computed using EvHA, a software program developed at the Max Planck Institute for Demographic Research. Given the size of the data set, virtually any estimated difference in risk level is statistically significant. Therefore, figures on variances and significance levels are not provided.

8 Since graduate students as a rule are employed by the university and do not receive student financial aid, they are not included here.

9 Since then the share has continued to decline and is now down to one percent (Statistics Sweden 2010). 


\section{Empirical results}

\section{Effects of the 1989 student financial aid reform}

The empirical evidence shows no clear effect of the 1989 financial aid reform on students' relative first birth risk. Among students in the youngest and oldest age groups, the trend in childbearing risk for the years following the reform is almost identical to that of the non-students (Figure 2). The childbearing risk for students aged 25-29 and 30-35 declined slightly after 1989 compared to non-students of the same age. Nevertheless, this decline seems to have started before the reform was implemented. Over the entire period 1984 to 1999, there is a slight decrease in first birth risk among students as compared to non-students. This decrease may be a reflection of the increasing difficulties young adults face in trying to enter the labour market or a desire for a stable economic situation prior to having children. The result is also consistent with Löfström's study (2003), which showed that completing education before having children was more important for young people in the 1990s than in the 1980s.

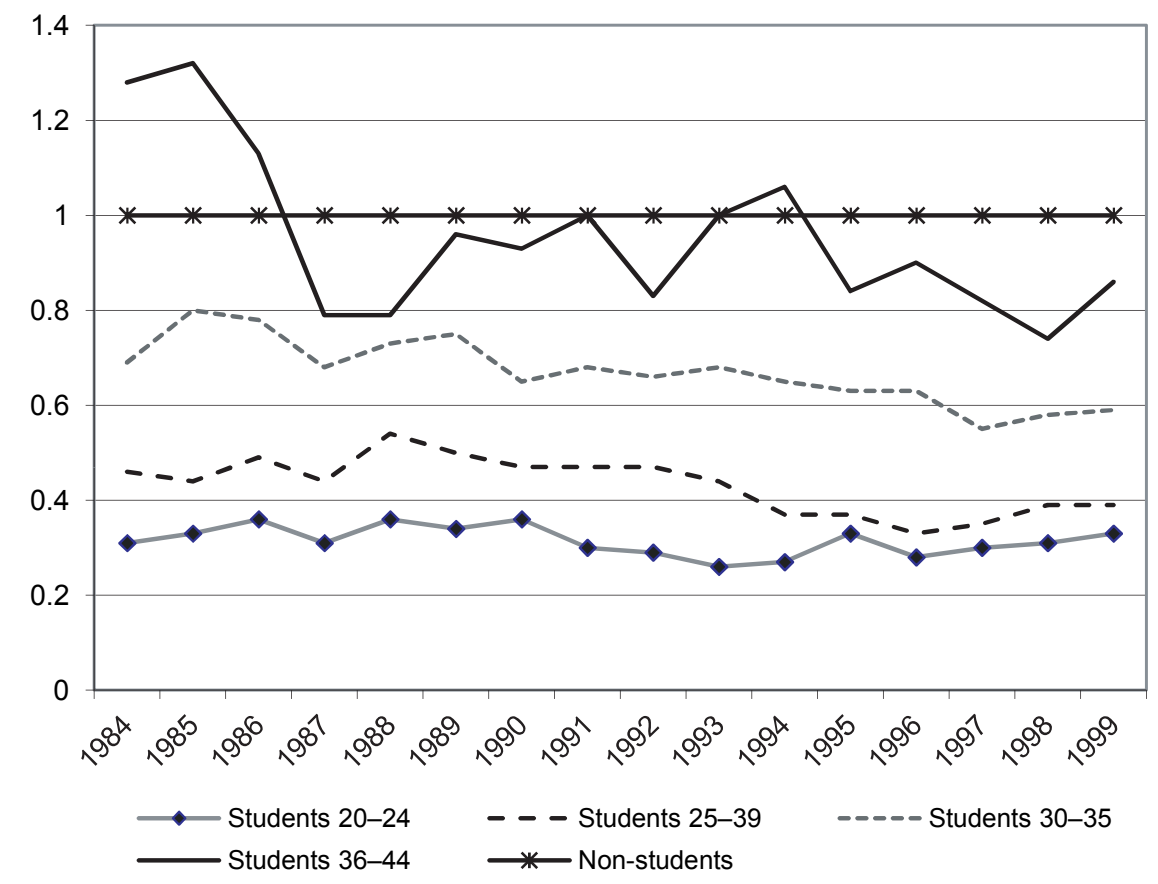

Figure 2. Relative risk of first birth for students versus non-students in the same age group, standardized for single-year age (separate model for each age group).

Compared to non-students, second and third birth risks among students remained fairly stable throughout the whole period (Figure 3). The only discrepancy is a dip in fertility among students in 1987 for which we have found no clear explanation. There is no relevant change in either family policy or educational policy at this time. The student 
aid reform of 1989 does not seem to have had any noticeable effect on either second or third birth risk among students. This holds for all age groups. For a student with three children who obtained full student grants, loans and child supplements, the reform decreased monthly income by approximately 2000 SEK (approximately $200 €$ ).

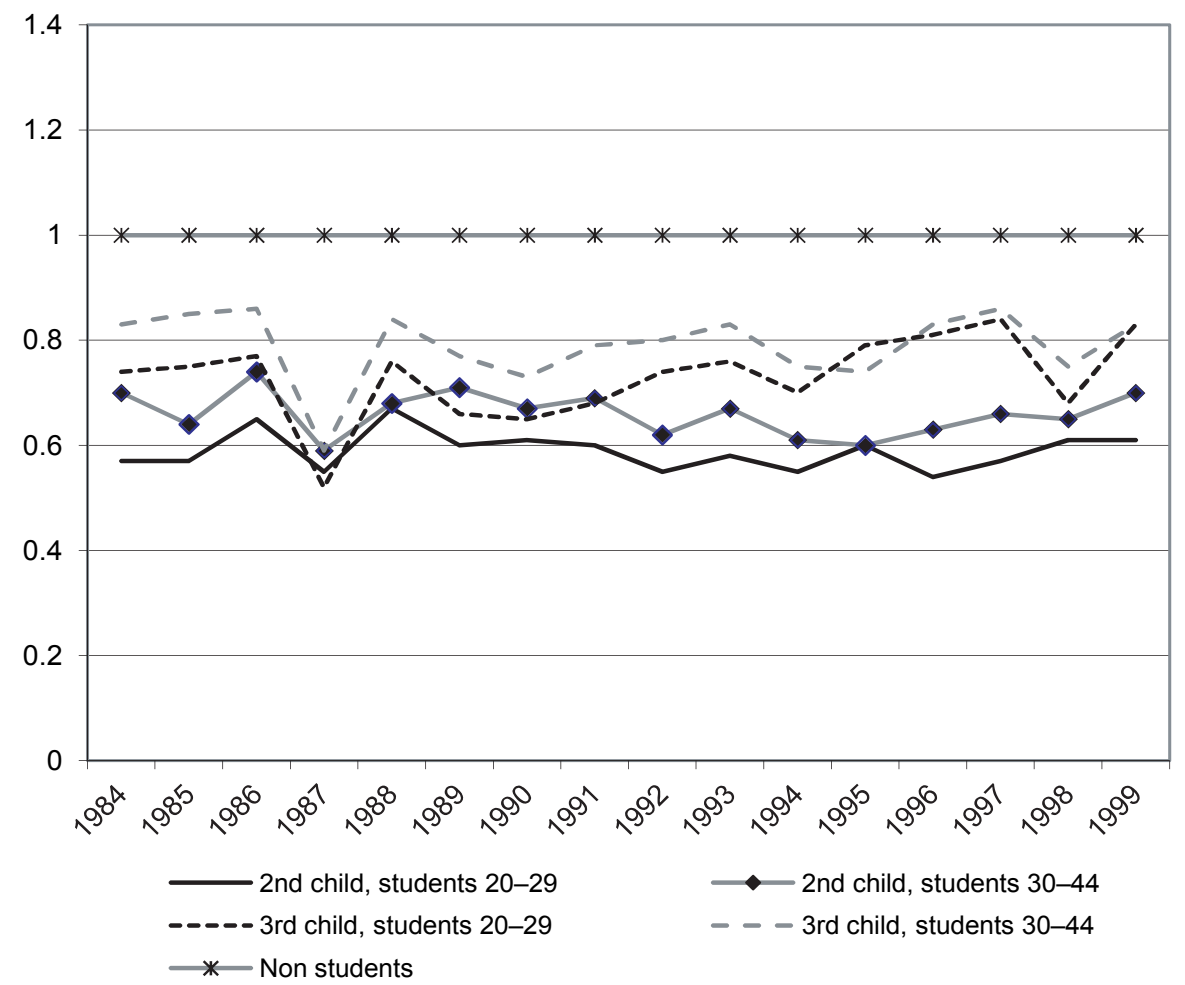

Figure 3. Relative risk of second and third births for students versus non-students in the same age group, standardized for single-year age (separate model for each group).

\subsection{The impact of age and income}

Figure 2, above, shows that the negative impact of student status on first birth risk strongly differs by age. The negative effect of being a student on first birth risk decreases with age. Controlling for income changes the picture somewhat (figure not shown). The difference in first birth risk between students and non-students becomes much smaller after accounting for income. This suggests that part of the reduced fertility of students is due to their lower income. The extent to which income affects the relative birth risk is partly dependent on age. When controls for income are added, students above 30 show about the same relative risk of giving birth as non-students. First birth risk among students in the oldest group (36-44) is even slightly higher than that of non-students. Most likely, students above age 36 have worked before entering university and could, therefore, be entitled to the earnings-related parental leave insurance. It is also likely 
that older women have a partner with a steady income. Another explanation may be that there is no time for further postponement of entry into motherhood for women in this age group. The fact that controlling for income reduces the negative effect of student status indicates that financial constraints account for a portion of the difference between students' and non-students' childbearing decisions.

The negative effect of student status on higher order birth risks is much weaker than for first birth risks. Similar to first birth, the negative effect of student status on second and third birth risk is stronger among younger age groups. Unlike first births, the effect of student status on second and third birth remains negative for all age groups even after controlling for income. Overall, controlling for income has less of an effect on second and third birth risk than on first birth. These results are in line with previous findings on the association between income and childbearing risks at higher parities in Sweden (see e.g. Andersson 2000 and Hoem and Hoem 1989). The weaker association may be partially explained by the "speed premium" in the Swedish parental leave system. Furthermore, the strong two-child norm implies that once the first child is born the second child most often follows "automatically" and that economic factors thus have a relatively weak impact on second birth risk (Andersson 2000; Andersson and Scott 2007). This relationship seems to apply to students as well.

\section{Discussion}

This study has shown that the student-benefit reform in 1989 did not have a noticeable impact on female students' childbearing behaviour. Thus, the negative effect of the reform may not have been as severe as some Swedish policy-makers seem to have believed. However, it should not be taken as an argument against the importance of economic factors in students' childbearing decisions. Since the non-repayable grant was raised substantially at the same time as the child supplement was removed, the economic consequences of the reform were mixed and supposedly of crucial negative importance only for a small number of low-income families with at least two children (or low-income families with one child, planning for a second one in the near future). Perhaps the fact that the child supplement was just a loan mattered. Since the student grant was raised by nearly the same amount, students who opted not to take the loan were better off after the reform, regardless of the number of children.

Moreover, controlling for earned income indicates that money does matter, since first birth risk among female students in all age groups are clearly affected by their income. This finding indicates that the postponement of childbearing until after completion of education is, to some extent, a matter of economic constraints. For second and third birth risk, controlling for income makes less of a difference. The weaker impact of economic factors on higher order birth risks is in keeping with previous research and this relationship seems to hold for students as well. Not surprisingly, the negative effect 
of being a student is weaker for second and third birth risks than for first births. Given that these students already have children, they are more likely to have a somewhat stable economic situation, and to be eligible for the earnings related parental leave, than students without children. Furthermore, since these students have already entered parenthood, and in that respect have also reached adult status, the student status and student life style are probably less of an obstacle for them than for childless students.

The study also shows that the impact of being a student on the propensity to become a mother, or to have another child, strongly differs by age. The negative effect of student status on birth risk is much stronger among the younger age groups, particularly when it comes to first birth risk. Most likely, older students have worked before entering university and are therefore entitled to earnings-related parental leave, and/or have a partner with a steady income. In addition, older student with previous labour market experience may feel that they are already established in adulthood. Another explanation may be that their fertility is not affected because there simply is no time for further postponement of entry into motherhood for these women.

In sum, even though the strength of association differs by income, parity and age, there is a consistent and stable negative effect of being a student on birth risks, indicating that combining studies and parenthood is perceived as difficult or undesirable. The outcome may be that either study (and consequently the entrance into qualified work life) or childbearing is postponed or forfeited. The various negative effects of these phenomena are frequently discussed in academia as well as in politics. Not only has the number of years spent in education been extended, it has also become more difficult for young people to enter and to establish themselves on the labour market. Postponed entry to the labour market may have negative consequences not only for society, but also for the individual who is unable to start an independent life with, for example, a separate household and family formation. Those who still choose to have children, despite not being established on the labour market, run the risk of ending up in a difficult economic situation. Moreover, their interrupted or postponed studies may later become an obstacle to labour market entry. While the increasing delay of first births may lead to more mature parents with a more stable economic situation, it is problematic from a demographic and a medical perspective. Given that fecundity declines with age, the need for assisted reproduction increases, which is costly and also associated with health hazards for mothers and children. Postponement of childbearing is also likely to lead to a higher level of childlessness, and an increase in the "unmet need for children" (Goldstein 2010).

One possible option to inhibit further postponement of childbearing would be to raise the minimum benefit level of the parental leave for students. This could be beneficial for women in particular, given that more women than men study and that women's fecundity declines more rapidly with advancing age. At the individual level it would increase the choice capacity of students and perhaps enable them to combine studies 
with parenthood. Since students in general have more flexible working hours than employees, this could be a favourable alternative for some students. Evidence indicates that students with children are actually more efficient in their studies, as female students with children obtain their diploma somewhat faster than those without children (Hallberg, Lindh et al. 2010). Moreover, having children before entering the labour market means that childbearing will not collide with the early intensive, and many times insecure, years as a new employee. It would also benefit employers who will not have to deal with finding a substitute while employees are on parental leave. On the negative side, raising the minimum benefit for students may weaken the dual-earner model, as well as the economic incentive for paid work. It may also extend young adults' educational period and further delay their establishment on the labour market.

To further investigate how students' childbearing behaviour is influenced by economic factors, it would be useful to separate students who are entitled to the earnings-related parental leave insurance from those who are not. This would provide a greater clarity regarding student-parents' economic prospects as well as their incentive to have children. Another suggestion for future research is to compare childbearing propensities among students enrolled in different educational fields and tracks. As previous studies have shown that women working in health care and teaching are less likely to become childless (Hoem et al. 2006), students in different fields of education are likely to differ also in their childbearing propensities as well as in their response to the financial aid reform. To further explore how the transition to adulthood is structured by money and policy, a cross-country comparison would be highly valuable. Even though institutional settings, as well as cultural norms, vary between countries, the general conclusions that the low childbearing of students to some degree seem to be a matter of economic constraint while modest changes in student financial aid have no noticeable effect on students' childbearing behaviour - may well be valid in countries outside Scandinavia. For more in-depth knowledge about the sequencing of life events during the transition to adulthood, qualitative data, such as in-depth interviews need to be incorporated as well. Yet another suggestion for future research is to follow young adults over a longer period of time and also investigate the possible effect of the child supplement introduced in 2006. Even though the supplement is not a very large amount of money, the existence of a child supplement for students signals that society supports a sequencing of life events where childbearing precedes the completion of education - a signal that, in turn, could influence established norms.

\section{Acknowledgements}

I would like to thank Gunnar Andersson, Ann-Zofie Duvander, Elizabeth Thomson and Thomas Lindh for their valuable advice and comments. Help from Carl-Johan Stolt at the Swedish agency in charge of financial aid for studies (CSN) is also highly appreciated 


\section{References}

Andersson, G. and K. Scott. 2007). Childbearing dynamics of couples in a universalistic welfare state: The role of labor market status, country of origin, and gender. Demographic Research 17(30): 897-938.

Andersson, G., A-Z Duvander and J. Hoem. 2005. Social differentials in speed-premium effects in childbearing in Sweden. Max Planck Institute for Demographic Research, Working paper 2005-027.

Andersson, G. 2000. The impact of labour force participation on childbearing behaviour: Pro-cyclical fertility in Sweden during the 1980s and the 1990s. European Journal of Population 15(1): 1-24.

Billari, F. C. and D. Philipov. 2004. Education and the transition to motherhood: A comparative analysis of Western Europe. European Demographic Research Papers 3.

Blossfeld, H.-P. and J. Huinink. 1991. Human capital investments or norms of role transition? How women's schooling and career affect the process of family formation. American Journal of Sociology 97(1): 143-168.

CSN. 2008a. Korta fakta. CSN i siffror [A few facts about CSN (the Swedish Governmental authority in charge of financial aid for studies). CSN in figures]. http://www.csn.se/om-csn/korta-fakta. Accessed August 2009.

CSN/ Stolt, C.-J. 2008b. Sammanställning över studiemedelsbelopp 1980-2008. [Compilation of student financial aid 1980-2008].

Ds. 2004:53. Ett barntillägg för studerande [A child supplement for students].

http://www.regeringen.se/sb/d/238/a/35854. Accessed August 2009.

Ds. 2001:57. Barnafödandet i fokus. Från befolkningspolitik till ett barnvänligt samhälle. [Childbearing in focus. From population policy to a family friendly society]. Socialdepartementet. http://www.regeringen.se/sb/d/108/a/891. Accessed August 2009.

Eriksson, H. 2009. Is economy most important? - A study of economic incentives for using temporary parental leave for care of sick children. Working Papers in Social Insurance 2009:1. Swedish Social Insurance Agency.

Eurydice. 1999. Key topics in education. Volume 1: Financial support for students in higher education in Europe. European Commission. http://eacea.ec.europa.eu/portal/ page/portal/Eurydice/showPresentation?pubid=007EN. Accessed August 2009.

Goldstein, J. 2010. A Behavioral Gompertz Model for cohort fertility schedules in low and moderate fertility populations. Max Planck Institute for Demographic Research, Working paper 2010-021.

Hallberg, D., T. Lindh, and J. Žamac. 2010. Educational choice, labor market entrance, and family career - in that order?. Paper presented at PAA Conference 2010, Dallas, U.S.A.

Hoem, J. M., G. Neyer and G. Andersson. 2006. Educational attainment and ultimate fertility among Swedish women born in 1955-59. Demographic Research 14(16): 381-404.

Hoem, B. 2000. Entry into motherhood in Sweden: The influence of economic factors on the rise and fall in fertility, 1986-1997. Demographic Research 2 (4).Available from: http://www.demographic-research.org/volumes/vol2/4/2-4.pdf

Hoem, J. M. 1993. Public policy as the fuel of fertility: effects of a policy reform on the pace of childbearing in Sweden in the 1980s. Acta Sociologica 36(1): 19-31.

Hoem, B. and J.M. Hoem. 1989. The impact of women's employment on second and third births in modern Sweden. Population Studies 43(1): 47-67. 
Kravdal, Ø. 1994. The importance of economic activity, economic potential and economic resources for the timing of first births in Norway. Population Studies 48(2): 249-267.

Lee, R. and J.R. Goldstein. 2003. Rescaling the life cycle: Longevity and proportionality. Population and Development Review 29: 183-207.

Lindh, T. 2008. Sverige i en åldrande värld - framtidsperspektiv på den demografiska utvecklingen [Sweden in an ageing world - future perspectives on demographic development]. Underlagsrapport nr 13 till Globaliseringsrådet, Education of Ministry.

Löfström, Å. 2003. Att lillan kom till jorden... Barnafödande och konjunktur under det sena 1990-talet [Childbearing and business cycles during the late 1990s]. Department of Economics, Umeå University.

Marini, M. 1984. The order of events in the transition to adulthood. Sociology of Education 57(2): 63-84.

Mayer, K. U and W. Müller. 1986. The state and the structure of the life course. In Sorensen, Weinert, and Sherrod (eds.) Human Development and the Life Course: Multidisciplinary Perspectives. Hillsdale, NJ: Lawrence Erlbaum Associates Publishers.

McDonald, P. 2000. Gender equity, social institutions and the future of fertility. Journal of Population Research 17(1): 1-16.

Neyer, G. and G. Andersson. 2008. Consequences of family policies on childbearing behaviour: effects or artefacts?", Population and Development Review 34(4): 699-724.

OECD. 2006a. Online Education Database http://www.oecd.org/document/54/0,3343 ,en_2649 39263238_38082166_1_1_1 37455,00.html. Accessed August 2009.

OECD. 2006b. Education at a Glance. http://www.oecd.org/dataoecd/47/51/37363421.xls. Accessed August 2009.

Shanahan, M. J. 2000. Pathways to adulthood in changing societies: variability and mechanisms in life course perspective. Annual Review of Sociology 26: 667-92.

Skirbekk, V., H. - P. Kohler and A. Prskawetz. 2004. Birth month, school graduation, and the timing of births and marriages. Demography, 41(3): 547-599.

Statistics Sweden. 2010. Online database. Levande födda efter region, kön och moderns ålder. År 1968-2009 [Live births by region, sex and age of mother]. http://www. ssd.scb.se/databaser. Accessed April 62010.

Statistics Sweden. 2009a. Universitet och högskolor. Studenter och examina på grundnivå och avancerad nivå 2007/08 [Universities and colleges. Students and degrees at basic and advanced level 2007/08]. http://www.scb.se/Statistik/UF/UF0205/2007L08B/ UF0205 2007L08B SM UF20SM0902.pdf. Accessed July 62009.

Statistics Sweden. 2009b. Online database. Befolkning. Summerad fruktsamhet efter kön. År 1970-2008 [Population. Total fertility by sex. Year 1970-2008] http://www. ssd.scb.se/databaser. Accessed August 2009.

Statistics Sweden. 2007. Högskolestuderandes levnadsvillkor. Enkätundersökning bland högskolestuderande våren 2007 [Living conditions among students in higher education. A survey. Spring 2007]. http://www.scb.se/Pages/PublishingCalendarViewInfo_ 259923. aspx?PublObjld=6514. Accessed August 2009.

SOU. 2003:130. Studerande och trygghetssystemen [Students and the social security system]. http://www.regeringen.se/sb/d/108/a/2570. Accessed August 2009. 
